\title{
Deontología Médica: Sobre la función de los profesionales de rectificar información errónea
}

\section{Al editor:}

El artículo de Southwell et al. (1) bien hace referencia al rol del colectivo médico en mitigar los efectos de la información errónea sobre los individuos que acuden al sistema de salud y el rol de las habilidades comunicacionales y emocionales para afrontar este problema. Pero probablemente restringir esta función al momento de la relación médico paciente sea insuficiente para confrontar con el creciente volumen e impacto de la información errónea que por su magnitud y multidimensionalidad emerge como un fenómeno complejo.

Un caso particular lo constituyen los profesionales de la salud que promueven posiciones que están basadas en información errónea. La incorporación de profesionales de la salud al colectivo de activistas de teorías sustentadas sobre información errónea produce un enorme perjuicio que potencia este tipo de mensajes y brinda un piso de legitimidad (ya que en principio esta validada por un experto) reduciendo la información brindada en la práctica individual a una confrontación "argumento versus argumento", donde el profesional muchas veces está en inferioridad de condiciones debido a la invasiva y enorme difusión de los mensajes brindados por estos profesionales. Es ahí que es válido reflexionar sobre los mecanismos con que cuentan los profesionales de la salud para contrarrestar esta desinformación, que por otro lado es masiva, viral y acompañada de una enorme cantidad de material audiovisual de fácil compartición.

El cuerpo médico, como cualquier colectivo en un determinado territorio, configura su identidad a través de las características subjetivas y objetivas de sus procesos productivos. Dentro de estos procesos no solo se incluyen procesos finales (como los serían los servicios curativos), sino también una serie de procesos de apoyo y estratégicos que sostienen a estos en esa compleja red que llamamos sistema de salud. Es decir, independientemente de su afiliación como practica liberal o socializada, es entendible que la práctica profesional se ejerce en un marco institucional y sistémico.

Los sistemas de salud, y en una escala mayor los sistemas sociales, cuentan con dispositivos que intentan corregir prácticas que tergiversen objetivos sociales sentidos (por ejemplo, quienes pueden ejercer el arte de curar). Pero probablemente el marco institucional sea más efectivo en definir una conducta (y cultura) adaptada a valores y normas sociales validadas. En este sentido algunas disciplinas, como la nueva economía institucional, nos ofrecen un ámbito interesante de comprensión sobre el peso de las normas (o reglamentaciones) y los incentivos para regular la práctica profesional en un ámbito institucional. Con esto se reconoce que la conducta profesional puede variar en un amplio rango en términos de bonhomía y calidad profesional y, por lo tanto, que las instituciones deben implementar mecanismos que protejan a los miembros de la organización y usuarios de conductas y actos desafortunados por parte de profesionales de la salud.

Mucho de los movimientos actuales en contra de prácticas médicas de comprobada eficacia se sostienen en información médica errónea, pero que fue generada, sostenida y promovida por profesionales médicos; por ejemplo, el trabajo del Dr. Gordon Stewart en el año 1974 en contra de la vacuna contra el coqueluche, o el más reciente trabajo de Andrew Wakefield de 1999 que asociaba la vacuna triple viral con enfermedad del espectro autista. Si bien ambos casos siguen dando sustento a movimientos naturistas, la comunidad científica no tardo en quitarle la legitimidad y exponer las falacias de los argumentos, una ventaja de los canales reconocidos de comunicación y de fomentar el espíritu crítico en las comunicaciones científicas $(2,3)$.

Sin embargo, nuevamente emerge el problema de profesionales de salud que se mueven en canales alternativos (de comunicación), sin un marco institucional y por lo tanto cuando trasgreden principios básicos como proveedores de servicios de salud no se ven expuestos a normas o sanciones y por el contrario, al centrar su estrategia comunicacional en un público susceptible recrean una comunidad que férreamente defiende posiciones erradas (y en ocasiones peligrosas) con una vocación casi religiosa que en ocasiones es casi imposible deconstruir. Esto no es un fenómeno nuevo, la consolidación de la identidad de la medicina en América se instituyo primariamente estableciendo los límites del ejercicio de la medicina y esta delimitación incluía además normas y reglamentaciones que penalizaban, por ejemplo, la charlatanería. Ese es el origen de prácticas corporativas en el ámbito de la medicina latinoamericana como lo son los códigos deontológicos, un Codex de buenas prácticas cuya singularidad residía en ser ejercidas por el mismo colectivo en resguardo de su profesión y bienestar de sus pacientes (4).

Probablemente sea necesario revisar y actualizar los códigos deontológicos y que el colectivo de profesionales de la salud tenga una actitud más activa en la defensa de asistencia médica como práctica humanista, racional y empírica; y en la defensa de los ciudadanos que se ven expuestos a prácticas que pueden 
perjudicar su salud en una asimetría de información que éticamente debemos igualar y no profundizar.

Conflicto de interés. Ninguno declarado.

Declaración. Las opiniones expresadas en este manuscrito son responsabilidad de los autores y no reflejan necesariamente los criterios ni la política de la RPSP/PAJPH y/o de la OPS.

\section{Sergio Fernando Jaime}

Universidad Nacional de la Patagonia San Juan Bosco, Comodoro Rivadavia, Argentina. $\bowtie$ Sergio Jaime, monchituc2@hotmail.com

Forma de citar Jaime Sergio. Deontología Medica: Sobre la función de los profesionales de rectificar información errónea. Rev Panam Salud Publica. 2021;45:e135. https://doi.org/10.26633/RPSP.2021.135

\section{REFERENCIAS}

1. Southwell BG, Wood JL, Navar AM. Función de los profesionales de la salud de rectificar la información errónea que tienen los pacientes más allá de corregir los hechos. Rev Panam Salud Publica. 2021;45:e60. https://doi.org/10.26633/RPSP.2021.60

2. Baker JP. The pertussis vaccine controversy in Great Britain, 19741986. Vaccine. 2003;21(25-26):4003-10. doi: 10.1016/s0264-410x (03)00302-5.
3. Godlee F, Smith J, Marcovitch H. Wakefield's article linking MMR vaccine and autism was fraudulent. BMJ. 2011 Jan 5;342:c7452. doi: $10.1136 /$ bmj.c7452.

4. Belmartino S. Historias de la profesión médica: Argentina y Estados Unidos en el siglo XX. Salud Colectiva. 2010 Dec 3;6(3):329. Disponible en: http://revistas.unla.edu.ar/saludcolectiva/article/ view / 288 